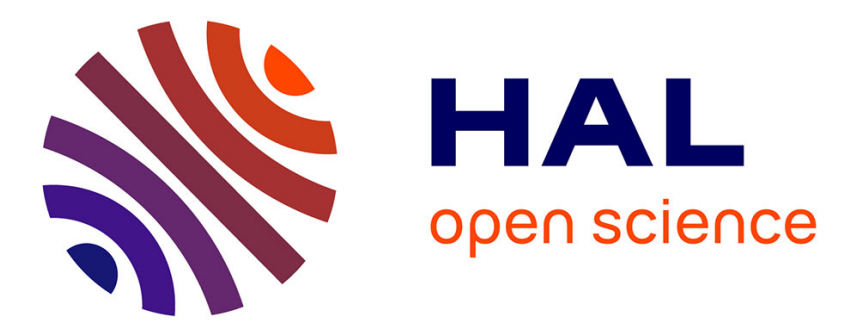

\title{
A one-century suite of seagrass bed maps: can we trust ancient maps?
}

\author{
Agathe Leriche, Charles F. Boudouresque, Bernard Guillaume, Patrick \\ Bonhomme, Jacques Denis
}

\section{- To cite this version:}

Agathe Leriche, Charles F. Boudouresque, Bernard Guillaume, Patrick Bonhomme, Jacques Denis. A one-century suite of seagrass bed maps: can we trust ancient maps?. Estuarine, Coastal and Shelf Science, 2004, 59 (2), pp.353-362. 10.1016/j.ecss.2003.09.007 . hal-03105927

\section{HAL Id: hal-03105927 \\ https://hal.science/hal-03105927}

Submitted on 11 Jan 2021

HAL is a multi-disciplinary open access archive for the deposit and dissemination of scientific research documents, whether they are published or not. The documents may come from teaching and research institutions in France or abroad, or from public or private research centers.
L'archive ouverte pluridisciplinaire HAL, est destinée au dépôt et à la diffusion de documents scientifiques de niveau recherche, publiés ou non, émanant des établissements d'enseignement et de recherche français ou étrangers, des laboratoires publics ou privés. 


\title{
A one-century suite of seagrass bed maps: can we trust ancient maps?
}

\author{
Agathe Leriche $^{\mathrm{a}, *}$, Charles-François Boudouresque ${ }^{\mathrm{a}, \mathrm{b}}$, Guillaume Bernard ${ }^{\mathrm{b}}$, \\ Patrick Bonhomme ${ }^{\mathrm{b}}$, Jacques Denis ${ }^{\mathrm{c}}$ \\ ${ }^{a}$ Centre d'Océanologie de Marseille, UMR CNRS no. 6540, Campus of Luminy, Case 901, 13288 Marseilles Cedex 9, France \\ ${ }^{\mathrm{b}}$ GIS Posidonie, Campus of Luminy, Case 901, 13288 Marseilles Cedex 9, France \\ ${ }^{\mathrm{C}}$ IFREMER, BP 330, 83507 La Seyne sur Mer Cedex, France
}

\begin{abstract}
To assess the dynamics of seagrass beds, it is necessary to be able to compare their present day and former distribution patterns. In most cases, ancient data are available in the form of maps whose reliability must be estimated before comparison. In the study area (near Marseilles, France), a series of maps of the seagrass Posidonia oceanica beds spanning more than one century (dating from 1883, 1897, 1958, 1975, 1979, 1991 and 2000, respectively) are available. In addition, a new map was established, using aerial photography (shallow areas), side scan sonar (deeper areas) and data validation by ground truth. In order to help assess the value of the ancient maps, a Reliability Index (RI) is proposed. The RI, rated from 0 to 50, weighs three parameters: (i) the initial scale of the map (source map) and the working scale (target map); (ii) the method of data acquisition (e.g. dredges, grabs, aerial photography, side scan sonar, scuba diving); and (iii) the method of data georeferencing. Dramatic differences in the distribution of seagrass beds are apparent between the eight maps. In view of the biological features of $P$. oceanica (e.g. slow rate of change of the meadow limits under natural conditions and the persistence of rhizomes after its death), it is possible that some of these differences may not reflect change over time but may be due to errors in the ancient maps. In contrast, other differences are plausible and validated by field data, e.g. the regression of the lower limit of the meadow. It was thus possible to compare the calculated RI for each map and the plausibility of observed differences as a basis for calibrating the RI.
\end{abstract}

Keywords: mapping; errors; aerial photography; side scan sonar; Posidonia oceanica; Mediterranean Sea

\section{Introduction}

Posidonia oceanica (Linnaeus) Delile is a seagrass endemic to the Mediterranean Sea which constitutes extensive meadows from sea level down to $25-40 \mathrm{~m}$ depth (depending upon water transparency). From the biological and physical perspective, in terms of primary production, export of detritus towards other ecosystems (Pergent et al., 1994), species diversity (Boudouresque et al., 1994), spawning and nursery opportunities for species of fishery interest (Francour, 1997), water move- ment and sediment flows (Gambi et al., 1989), these meadows represent a key ecosystem. Due to the length (up to $120 \mathrm{~cm}$ ) and density of the leaves (up to 10000 per $\mathrm{m}^{2}$ ), the meadows trap sediments. Rhizomes react to burial by vertical growth, so that the sea bottom rises. Within the sediment, the deeper parts of the rhizomes die but their decay is very slow, so that they can persist for millennia. The terrace constituted by live and dead intertwined rhizomes, together with the sediment which fills the interstices, is named "matte" (Molinier and Picard, 1952; Boudouresque et al., 1980a,b). The $P$. oceanica meadow constitutes the climax ecosystem on most Mediterranean subtidal bottoms. In the absence of human impact, it already occupies all suitable areas (Molinier and Picard, 1952). Under such conditions, the 
shoot density does not present significant changes and the meadow limit shift does not exceed a few centimetres per year, as evidenced by a 15-year monitoring survey (Boudouresque et al., 2000). The main limiting factors for $P$. oceanica are dim light $(10-16 \%$ of sea surface irradiance), low salinity (33), temperature (below $10^{\circ} \mathrm{C}$ and above $30{ }^{\circ} \mathrm{C}$ ) and sediment input (above $70 \mathrm{dm}^{3}$ $\mathrm{m}^{-2} \mathrm{a}^{-1}$ ) (e.g. Ben Alaya, 1972; Ott, 1979; Boudouresque and Jeudy de Grissac, 1983; Alcoverro et al., 2001; Ruiz and Romero, 2001). P. oceanica beds are very sensitive to disturbance caused by human activity, e.g. coastal development (Meinesz et al., 1991a), pollution (Delgado et al., 1999; Pergent et al., 1999), turbidity (Ruiz and Romero, 2001), anchoring (Porcher, 1984; Francour et al., 1999) and trawling (Ardizzone and Pelusi, 1984; Sánchez-Lizaso et al., 1990; Martín et al., 1997; Pasqualini et al., 1999, 2000). As a result, their disappearance has been observed in a number of regions (e.g. Augier and Boudouresque, 1970; Meinesz et al., 1991a; Ramos-Esplá et al., 1994). When P. oceanica dies, the "matte" (hereafter "dead matte") persists, since the decay of the rhizomes is very slow. This feature makes it possible to definitely assess the past presence of a meadow in areas where it is nowadays absent.

Mapping the distribution of the seagrass Posidonia oceanica meadows is a valuable tool for developing our understanding of this natural resource and for the management of coastal areas. Knowing the location of the seagrass meadows makes it possible to locate new port facilities, sewage outfalls, etc. outside areas occupied by the seagrass. Furthermore, the monitoring of human impact requires accurate maps. Mapping methods include the use of dredging, grabs, scuba diving, small submersibles, towed underwater cameras, aerial photographs, satellite imagery and side scan sonar. The relative accuracy of these different methods is highly variable (Meinesz et al., 1981; Belsher et al., 1988; Meinesz et al., 1991b).

In some coastal regions, ancient maps are available. Do they provide a reliable basis for inferring changes over time in the surface area of the seagrass beds? The Mediterranean study area, located near Marseilles (Provence, France), has been chosen because seven earlier maps of the seagrass Posidonia oceanica beds are available (the oldest from the end of the 19th century), in addition to a newly established map. Scales range from $1 / 2600$ to $1 / 460000$ and a variety of methods were used. The problem addressed here is how to interpret their differences: changes over time or errors? As a basis for drawing conclusions, a Reliability Index for these ancient maps is proposed.

\section{Materials and methods}

\subsection{Study area}

The study area is located to the west of Marseilles (Fig. 1). Potential human impact takes the form of pollution discharges by the Rhône river $(70 \mathrm{~km}$ to the

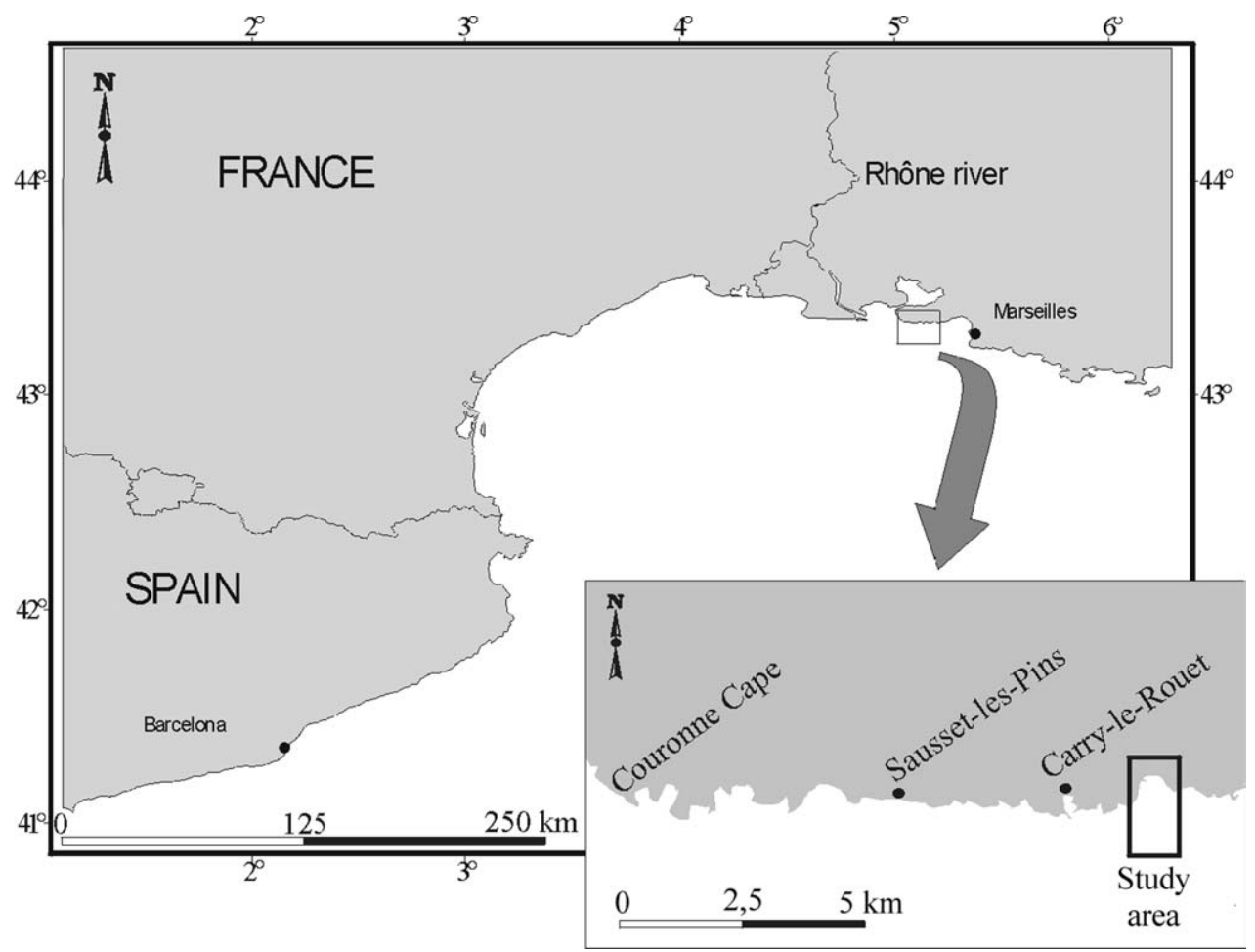

Fig. 1. Geographical location of the study area. 
west), the port facilities of Fos (25 km west) and Marseilles (15 km east), two small pleasure boat harbours (Carry-le-Rouet, $2 \mathrm{~km}$ west, and Le Rouet) and trawling.

\subsection{New and ancient maps}

The new map of Posidonia oceanica distribution was established using aerial photography (shallow areas, i.e. $<10 \mathrm{~m}$ ) and side scan sonar (deeper areas). These data were validated by ground truth. The aerial colour photograph (1/15000) was taken on July 21, 2001 from a plane equipped for vertical photography flying at $325 \mathrm{~m}$, with a photogrammetric Zeiss camera $(23 \mathrm{~cm} \times$ $23 \mathrm{~cm}$, focal $152 \mathrm{~mm}$; film AGA P 200), according to a standardized protocol (Lefèvre et al., 1984). It was digitised (800 dpi) with an Agfa SnapScan $600^{\circledR}$ colour scanner using Corel Photo Paint $8^{\circledR}$ software in 16.7 million colours. Pre-processing involved specific geometrical correction in order to eliminate distortions in the photograph (Pasqualini et al., 1998). This correction was achieved by means of the extension Géoref-Image ${ }^{\circledR}$ version $2.2 b$ of the Geographic Information System (GIS) ArcView 3.2 ${ }^{\circledR}$ software, from "orthophotoplans" (photographs adjusted from two colour negatives taken with different optical axes with a geographical referencing accuracy of $1 \mathrm{~m}$ ) of the $\mathrm{Bd}$-ortho ${ }^{\circledR}$ (Institut Géographique National; France). Reference points were taken from the terrestrial parts of the photograph. Patches of seagrass were delimited by feature extraction process by means of ImageAnalysis ${ }^{\circledR}$ (extension of Arc view 3.2). Some pixels are selected within a homogeneous region identified as $P$. oceanica. These pixels are used to define the classification rule in each color band of the photography. Pixels around these selected pixels are classified step by step. The classifier looks at the pixel values of the additional pixel to see if they fall within the determined range. If it is the case, they are included in the closed polygon which delimits the patch of seagrass. Additional polygons were delimited manually when they were perceptible, although not taken into account by Image-analysis. Side scan sonar images (EdgeTech DF $1000 \mathrm{DCI}^{\circledR}$ ) were obtained during the oceanographic campaign Posicart I of the vessel Téthys II in June 2000 (for rationale and principles of side scan sonar, see Pasqualini et al., 1998; Brown et al., 2002). The numerical data acquisition system is of the TEI ISIS type on a PC platform under Windows. The data files in *.XTF format are stored on standard DOS $(2.3$ Go or $5.2 \mathrm{Go}$ ) magneto-optical discs. The navigation data are of the NMEA0183 type. The images obtained (sonograms) indicate the distribution and boundaries of the different substratum, sediment and seagrass bottoms which are characterised by different shades of grey. The sonograms were rectified with respect to a map indicating the location of the vessel's route. The information obtained from the sonograms was manually transferred to the map. This map was then digitised using a colour scanner. Possible misinterpretation of both the aerial photographs and the sonograms (e.g. patches of drift dead $P$. oceanica leaves lying on a sand bottom) and doubtful points of interpretation were resolved by scuba diving ground truth. During the programme, 18 pinpoint and 7 transect dives were performed. Exact location of the dives was obtained by means of a GPS (Global Positioning System; Maggellan $315^{\circledR}$ ).

In addition to the new map, seven ancient maps of Posidonia oceanica distribution were used for comparison (Table 1). In order to make easier and more accurate comparison between these maps and the new map, they were digitised in the same way as the aerial photographs, except for the resolution (300 dpi). The limits of the seagrass bed and the shoreline were manually redrawn using the Corel Draw $8^{\circledR}$ software. Geographical referencing was carried out on files in Autocad (dxf) format after conversion into shape file under ArcView ${ }^{\circledR}$ by means of the Géoref-Image ${ }^{\circledR}$ version 2.2 module from IGN orthophotoplans.

\subsection{Reliabilty Index}

In order to help estimate the value of ancient maps, a Reliability Index (RI) is proposed, which weighs three parameters: the scale of the map (10 points), the method of data acquisition (presence or absence of Posidonia oceanica) (20 points) and the method of geographical location of the data ( 20 points). The RI is the sum of these three ratings.

The rating of the scale takes into account two features (Table 2). First, the initial scale of the source map. The larger the scale, the greater the a priori accuracy of the map. Second, the ratio between the initial scale (source map) and the working scale (target map). For a given source scale, decreasing the working

Table 1

Inventory of seagrass Posidonia oceanica maps for the study area. From Jeudy de Grissac et al. (unpubl. data) and Pergent and PergentMartini (unpubl. data), updated

\begin{tabular}{lll}
\hline Reference & $\begin{array}{l}\text { Year of } \\
\text { mapping }\end{array}$ & $\begin{array}{l}\text { Scale of } \\
\text { the map }\end{array}$ \\
\hline Marion (1883) & 1883 & $1 / 125000$ \\
Pruvot (1897) & 1897 & $1 / 460000$ \\
Picard J. (unpublished data) & 1958 & $1 / 71922$ \\
Blanc (1975) & 1975 & $1 / 125000$ \\
Cristiani G. (unpublished data) & 1979 & $1 / 5000$ \\
Niéri M., Francour P., Sinassamy J.M., & 1991 & $1 / 2600$ \\
$\begin{array}{l}\text { Urscheller F. and Fleury M.C. } \\
\quad \text { unpublished data) }\end{array}$ & & \\
$\quad \begin{array}{l}\text { Bernard G., Bonhomme P., Ruitton S., } \\
\text { Escoffier B. and Cadiou G. }\end{array}$ & 2000 & $1 / 50000$ \\
$\quad$ (unpublished data) & & \\
\hline
\end{tabular}




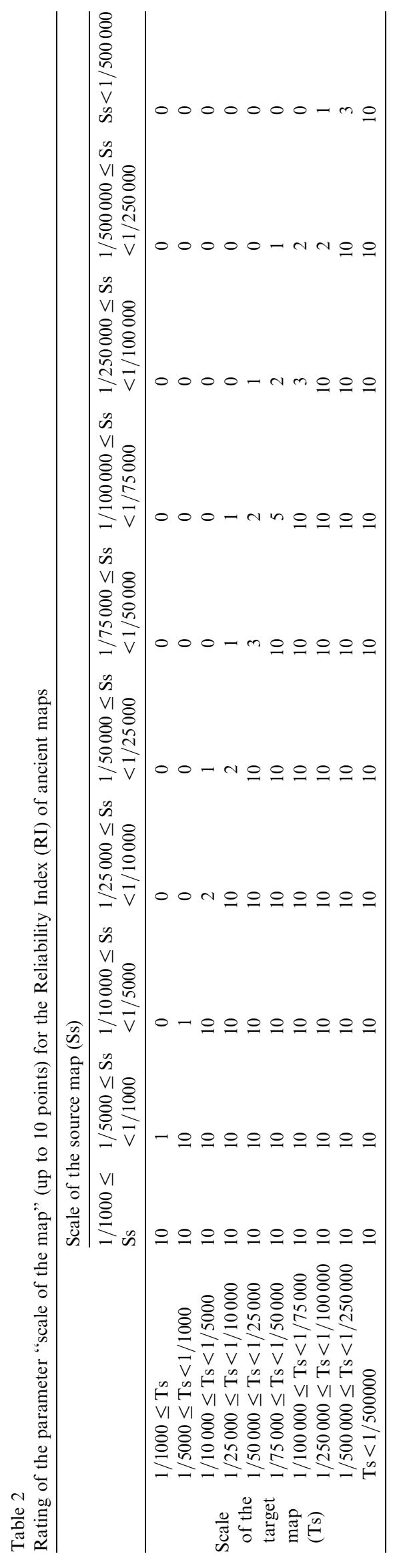

Table 3

Rating of the parameter "method of data acquisition" (up to 20 points) for the Reliability Index (RI) of ancient maps, according to the depth $(\mathrm{G}=$ grid size $)$

\begin{tabular}{lccc}
\hline Method of data acquisition & $0-5 \mathrm{~m}$ & $5-15 \mathrm{~m}$ & $>15 \mathrm{~m}$ \\
\hline Dredges, grabs, sounding lead & & & \\
$\mathrm{G}>1000 \mathrm{~m}$ & 0 & 0 & 0 \\
$1000 \mathrm{~m} \geq \mathrm{G}>750 \mathrm{~m}$ & 0 & 0 & 0 \\
$750 \mathrm{~m} \geq \mathrm{G}>500 \mathrm{~m}$ & 0 & 0 & 0 \\
$500 \mathrm{~m} \geq \mathrm{G}>250 \mathrm{~m}$ & 1 & 1 & 1 \\
$250 \mathrm{~m} \geq \mathrm{G}>100 \mathrm{~m}$ & 3 & 3 & 3 \\
$100 \mathrm{~m} \geq \mathrm{G}>50 \mathrm{~m}$ & 8 & 8 & 8 \\
$50 \mathrm{~m} \leq \mathrm{G}$ & 13 & 13 & 13 \\
Diving, submersible, towed & & & \\
underwater camera & & & \\
$\mathrm{G}>1000 \mathrm{~m}$ & 0 & 0 & 0 \\
$1000 \mathrm{~m} \geq \mathrm{G}>750 \mathrm{~m}$ & 1 & 1 & 1 \\
$750 \mathrm{~m} \geq \mathrm{G}>500 \mathrm{~m}$ & 3 & 3 & 2 \\
$500 \mathrm{~m} \geq \mathrm{G}>250 \mathrm{~m}$ & 5 & 5 & 5 \\
$250 \mathrm{~m} \geq \mathrm{G}>100 \mathrm{~m}$ & 10 & 10 & 10 \\
$100 \mathrm{~m} \geq \mathrm{G}>50 \mathrm{~m}$ & 15 & 15 & 15 \\
$50 \mathrm{~m} \leq \mathrm{G}$ & 10 & 2 & 0 \\
Satellite imagery without ground truth & 10 & 5 \\
Satellite imagery with ground truth & 15 & 5 & 0 \\
Aerial photography without ground & 15 & 10 & 0 \\
truth & & & \\
Aerial photography with ground truth & 20 & 15 & 0 \\
Side scan sonar without ground truth & 0 & 15 & 15 \\
Side scan sonar with ground truth & 0 & 20 & 20 \\
\hline
\end{tabular}

scale increases the reliability and for a given working scale, the larger the source scale, the higher the reliability.

The rating of the method of data acquisition (Table 3) accounts for the reliability of the mapped theme (presence or absence of the seagrass) at a given point of the map. Two types of methods are to be considered: those leading to discrete data and those leading to continuous data (Meinesz et al., 1981). Examples of the first type of methods are sounding leads (a method no longer utilised), dredges, grabs, scuba diving and towed underwater camera. The accuracy depends upon the mesh size of the grid, whatever the depth. As far as the identification of the type of bottom is considered, it is generally unequivocal. It is lower for sounding leads, dredges and grabs due to the fact that misinterpretation can result from the presence of drift material on the bottom. Methods leading to the acquisition of continuous data are satellite imagery, aerial photography and side scan sonar. The contours are usually obvious, but the identification of the contoured type of bottom often proves to be doubtful. In addition, depth matters for satellite imagery and aerial photography. In the northwestern Mediterranean, satellite imagery and aerial photography are disappointing below $5 \mathrm{~m}$ and $15 \mathrm{~m}$ depth, respectively (Meinesz et al., 1981; Belsher et al., 1985, 1988; Meinesz et al., 1988, 1991a; Paillard et al., 1993; Pasqualini et al., 1999). In contrast, side scan sonar is ineffective in shallow waters (Meinesz et al., 
Table 4

Rating of the parameter "accuracy of the data positioning" (up to $10+10$ points) for the Reliability Index (RI) of ancient maps based upon discrete data ( $\mathrm{D}=$ dredging; $\mathrm{M}=$ other methods)

\begin{tabular}{|c|c|c|c|c|}
\hline $\begin{array}{l}\text { Accuracy of data acquisition: } \\
\text { in situ positioning }\end{array}$ & $\begin{array}{l}\text { Rating } \\
\text { (D) }(/ 10)\end{array}$ & $\begin{array}{l}\text { Rating } \\
(\mathrm{M})(/ 10)\end{array}$ & $\begin{array}{l}\text { Accuracy of the data transfer } \\
\text { to the map: used method }\end{array}$ & $\begin{array}{l}\text { Rating } \\
(\mathrm{D}, \mathrm{M})(/ 10)\end{array}$ \\
\hline None & 0 & 0 & None & 0 \\
\hline GPS before 2000 & 2 & 6 & $\begin{array}{l}\text { Manual (from land-marks, GPS, } \\
\text { triangulation or dGPS data) }\end{array}$ & 7 \\
\hline $\begin{array}{l}\text { Triangulation, dGPS before } 2000 \text {, } \\
\text { land-marks }\end{array}$ & 2 & 8 & $\begin{array}{l}\text { Input of geographical coordinates into } \\
\text { a GIS software }\end{array}$ & 10 \\
\hline GPS since 2000 & 2 & 9 & & \\
\hline dGPS since 2000 & 2 & 10 & & \\
\hline
\end{tabular}

1981). For all continuous methods, accuracy is strongly improved where ground truth is performed.

The rating of the accuracy of the data positioning (Tables 4-7) accounts for positioning of data both during acquisition ( 5 or 10 points) and when transferred to the map (10 or 15 points). Here, four methods are to be considered separately. For maps based upon discrete data (Table 4), the accuracy of the in situ positioning depends on the method used: it is generally considered to be of the order of $\pm 20 \mathrm{~m}$ (GPS before 2000), $\pm 10 \mathrm{~m}$ (dGPS before 2000, triangulation and land-marks), \pm 5 $\mathrm{m}$ (GPS since 2000) and $\pm 1 \mathrm{~m}$ (dGPS since 2000) (Meinesz et al., 1998; Pasqualini et al., 1998, 1999). When data are acquired by means of dredges, the accuracy of in situ positioning appears to be of lesser relevance; dredging covers an area at least several tens of meters long, often more than $100 \mathrm{~m}$. For this reason, dredging is rated differently from other methods (Table 4). For maps based on aerial photography (Table 5), the use of photographs from specially designed aerial campaigns, with an optimal standardized protocol (Lefèvre et al., 1984), increases the accuracy of the data positioning, in contrast with photographs taken for other aims, generally terrestrial ones. For maps based upon side scan sonar (Table 6), the location of the GPS, directly on the sonar-fish, avoids correcting the sonar position from the ship's position and therefore improves the accuracy of the data positioning. Finally, for maps based upon satellite imagery (Table 7), the resolution depends both on the type of satellite and the mode of image processing used (e.g. multispectral or panchromatic) (Belsher et al., 1985, 1988).

Different ratings may be attributed to the different parts of a given map, when it encompasses different depths and/or when different methods were used, e.g. according to the depth. The methods used may be too poorly described to make possible the accurate rating of a map. When this is the case, either missing data were directly obtained from questioning the author (Blanc, 1975 map), or the lowest rating was attributed for the missing point (e.g. 1897 and 1980 maps).

It goes without saying that rating the RI relies on the empirical weighting of the different methodological criteria. In addition, other criteria could be included in the RI, e.g. slope of the bottom, sensitiveness of the film and number of ground truth dives per surface unit (Pasqualini V., pers. comm.). However, these criteria are usually not available for ancient maps.

\section{Results}

Dramatic differences in seagrass distribution are apparent between the eight available maps (Fig. 2). The 1883 map shows a seagrass meadow continuous below $15 \mathrm{~m}$ depth and restricted to the centre of the bay in shallow waters. At the turn of the 19th century, the meadow seems to have disappeared above $20 \mathrm{~m}$ depth (1897). This decline is doubtful in the absence of known possible human impact in the area. In addition, the seagrass meadow goes as deep as below $40 \mathrm{~m}$, a feature that is today only found in very rare conditions of water transparency (Augier and Boudouresque, 1979; Boudouresque et al., 1990). In contrast, the 1958 map indicates a seagrass meadow completely occupying the bay. This would imply a spread of the seagrass limit towards the shore of more than $1 \mathrm{~km}$, which is hardly credible. The horizontal growth of Posidonia oceanica plagiotropic rhizomes never exceeds $10 \mathrm{~cm}$ per year and averages, over long periods, $4 \mathrm{~cm}$ per year (Meinesz and Lefèvre, 1984; Mossé, 1984). The 1975 map is the first that begins to look like the present day map. The axis of the bay is devoid of seagrass meadow; this is a common

Table 5

Rating of the parameter "accuracy of the data positioning" (up to $5+15$ points) for the Reliability Index (RI) of ancient maps based upon aerial photography. $\mathrm{Ra}=$ Reference coordinates accuracy. $\mathrm{Pa}=$ Photograph accuracy

\begin{tabular}{lllc}
\hline $\begin{array}{l}\text { Accuracy of data } \\
\text { acquisition: specially } \\
\text { designed aerial } \\
\text { campaign }\end{array}$ & $\begin{array}{l}\text { Rating } \\
(/ 5)\end{array}$ & $\begin{array}{l}\text { Accuracy of the } \\
\text { data transfer to } \\
\text { the map: geometrical } \\
\text { correction }(\mathrm{GC})\end{array}$ & $\begin{array}{l}\text { Rating } \\
(/ 15)\end{array}$ \\
\hline No & 0 & $\begin{array}{l}\text { None } \\
\text { GC with } \mathrm{Ra}<\mathrm{Pa}\end{array}$ & 0 \\
Yes & 5 & GC with $\mathrm{Ra}>\mathrm{Pa}$ & 10 \\
\hline
\end{tabular}


Table 6

Rating of the parameter "accuracy of the data positioning" (up to $5+5+10$ points) for the Reliability Index (RI) of ancient maps based on side scan sonar data. $\mathrm{Sr}=$ Sonar resolution

\begin{tabular}{|c|c|c|c|c|c|}
\hline \multicolumn{4}{|l|}{ Accuracy of data acquisition } & \multirow{2}{*}{$\begin{array}{l}\text { Accuracy of the data transfer to the } \\
\text { map: used method }\end{array}$} & \multirow{2}{*}{$\begin{array}{l}\text { Rating } \\
(/ 10)\end{array}$} \\
\hline $\begin{array}{l}\text { Side scan sonar } \\
\text { positioning method }\end{array}$ & $\begin{array}{l}\text { Rating } \\
(/ 5)\end{array}$ & $\begin{array}{l}\text { Resolution of the used } \\
\text { side scan sonar }\end{array}$ & $\begin{array}{l}\text { Rating } \\
(/ 5)\end{array}$ & & \\
\hline Corrected position of the ship & 2 & $\mathrm{Sr}<10 \mathrm{~m}$ & 3 & Manual & 5 \\
\hline GPS on the sonar & 3 & $10 \mathrm{~m}<\mathrm{Sr}<1 \mathrm{~m}$ & 4 & $\begin{array}{l}\text { Input of digital data by means of a } \\
\text { mosaic computation software }\end{array}$ & 10 \\
\hline dGPS on the sonar & 5 & $\mathrm{Sr}>1 \mathrm{~m}$ & 5 & & \\
\hline
\end{tabular}

feature of $P$. oceanica meadows in narrow bays, due to bottom erosion by the rip current which flows when winds are blowing onshore. Comparison with the present-day map shows that, since that time, the seagrass meadow had apparently spread over $100 \mathrm{~m}$ (west side of the bay) and $500 \mathrm{~m}$ (east side), which is impossible.

The four more recent maps (Fig. 2) are closely related. Conspicuous differences are, however, to be noted. For example: (1) Along the east side of the bay, the 1979 map only records four small patches of Posidonia oceanica, where a continuous strip is shown in the other maps. (2) The 1991 map fails to show patches in front of the east side of the seagrass meadow of the west part of the bay. (3) The southern part of the axial area without seagrass appears to be more extensive in the 2000 and the present-day maps when compared with those of 1979 and 1991. (4) In the northwestern part of the bay, the seagrass meadows reach Rouet harbour and the shore in the $1991 \mathrm{map}$, in contrast to the others. (5) Again in the northwestern part of the bay, the upper limit of the seagrass meadow appears as divided into a number of patches in the 2000 and present day maps, whereas it has a clear outline in the 1979 map.

So, differences do exist between ancient and present maps, but also between maps of roughly the same age. Some of these differences are clearly irrelevant. Other differences may be artefacts occurring in the course of the digitisation and manual redrawing process (Iehlé et al., 1995). Here the resolution of digitisation (300 dpi) is sufficient to minimize these artefacts. Other artefacts could be due to geometrical correction. With the

\section{Table 7}

Rating of the parameter "accuracy of the data positioning" (up to $5+5+10$ points) for the Reliability Index (RI) of ancient maps based on satellite imagery. Ir = image resolution

\begin{tabular}{|c|c|c|c|}
\hline $\begin{array}{l}\text { Accuracy of data } \\
\text { acquisition: image } \\
\text { resolution }\end{array}$ & $\begin{array}{l}\text { Rating } \\
(/ 10)\end{array}$ & $\begin{array}{l}\text { Accuracy of the data } \\
\text { transfer to the map: } \\
\text { used method }\end{array}$ & $\begin{array}{l}\text { Rating } \\
(/ 10)\end{array}$ \\
\hline $\mathrm{Ir}<40 \mathrm{~m}$ & 2 & Manual & 5 \\
\hline $40<\operatorname{Ir}<10 \mathrm{~m}$ & 6 & & \\
\hline $10<\operatorname{Ir}<1 \mathrm{~m}$ & 8 & $\begin{array}{l}\text { Input of digital data } \\
\text { into a GIS software }\end{array}$ & 10 \\
\hline $\mathrm{Ir}>1 \mathrm{~m}$ & 10 & & \\
\hline
\end{tabular}

exception of the two oldest maps (1883: $6.04 \mathrm{~m}$; 1893: $19.28 \mathrm{~m})$, and the $1975 \mathrm{map}(4.83 \mathrm{~m})$, the accuracy of the geometrical correction is less than $2 \mathrm{~m}$ and could not explain the differences which are observed between maps. Finally, differences between maps may reflect change with time in the seagrass bed surface area. Before making any attempt to interpret these differences, it is necessary to assess the reliability of these maps. RI was calculated for the seven ancient maps available for the study area together with the new established one (Table 8).

Considering that most major changes from map to map are biologically irrelevant (see above), whatever their age, the RI should be correlated with their percentage of similarity with the present map, assumed to be the best. Differences between maps that are not taken into consideration by the RI (artefacts during the digitisation and manual redrawing process or during specific geometrical rectification) have in fact a minor impact on the similarity. Spearman correlation ranks (Rs) between the RI and similarity (Sørensen Similarity Index; Sørensen, 1948) validate the former $(<5 \mathrm{~m}$ : $\mathrm{Rs}=0.82 ; 5-15 \mathrm{~m}: \mathrm{Rs}=0.96$ and $>15 \mathrm{~m}: \mathrm{Rs}=0.82$, all correlations significant at least at $5 \%$ level).

\section{Discussion}

To revert to the initial question: can we trust ancient maps? Fortunately, as far as Posidonia oceanica beds are concerned, and in contrast with some other benthic communities, biological features make it possible to reject explicitly some of them (the 1883, 1897, 1958 and 1975 maps). Their RI is below 25, a value that can thus be proposed as the critical level for total rejection. RI values $>25$ and $<40$ (e.g. shallow areas of the 1979 and 1991 maps) are to be considered with caution. Some localized incongruities were detected (Fig. 2). Finally, maps with RI values $\geq 40$ are for the most part credible. An area without $P$. oceanica strongly expanded between 1991 and the present (Fig. 2: vi). During the same period, the lower limit of the meadow moved back (Fig. 2: vii). This is congruent with very accurate data from the Posidonia Monitoring Network (Boudouresque et al., 2000), based on the setting up of cement markers 

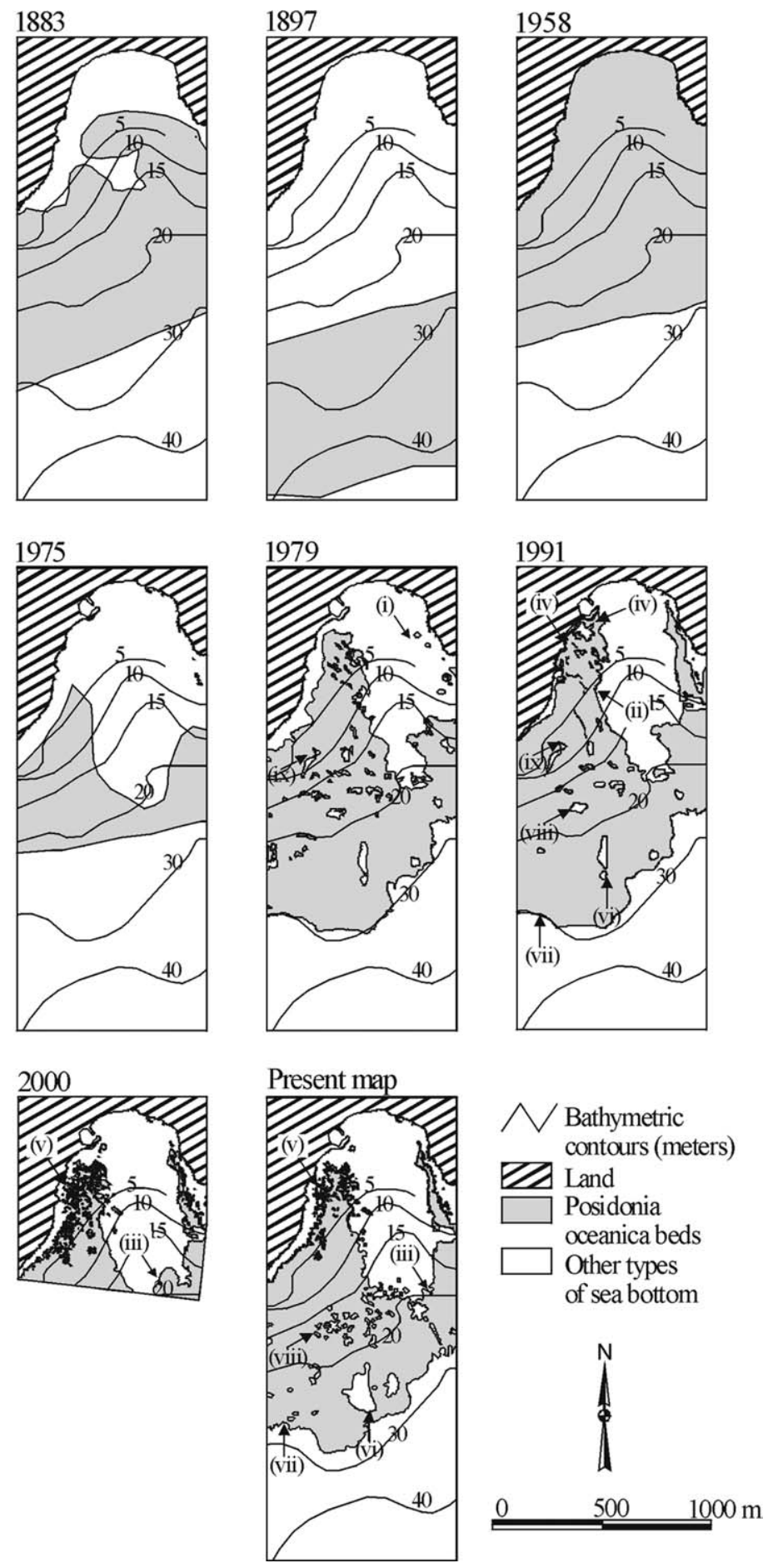

Fig. 2. Ancient maps available for the study area and present map. Arrows i-ix indicate conspicuous differences between maps from 1980 up to the present (see text).

at the lower limit of the meadow: a more or less general regression of the limit was observed in the study region. An area devoid of $P$. oceanica, which was isolated in 1991, is now surrounded by many smaller patches (Fig. 2: viii). Other differences may be artefacts or the result of actual change. A linear and straight patch seems to have moved westwards from 1980 to 1991 , then to have disappeared (Fig. 2: ix). Such a shift is possible, due to water movement which erodes the meadow on one side of the patch while it is recolonized on the opposite side; disappearance may occur when recolonization is faster than erosion (Boudouresque et al., 1980a,b). On the other hand the shift may be an artefact due to specific geometrical correction. 


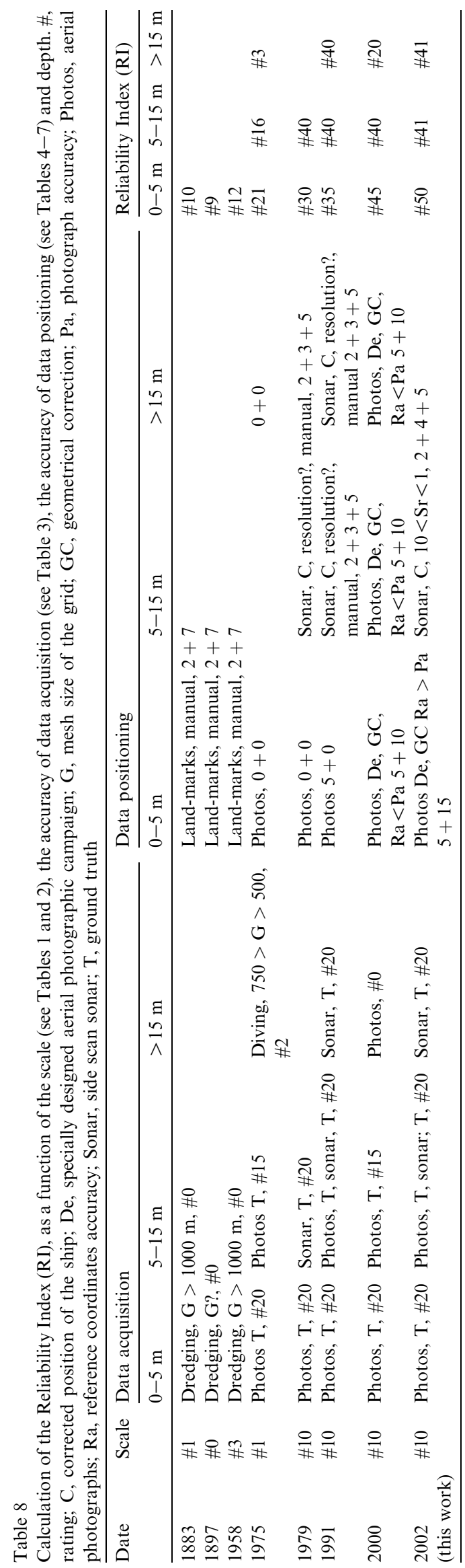

Ancient maps of seagrass beds are usually available for many areas of the marine realm. For the study area, a series of maps spanning more than one century were available. Biological features of the seagrass Posidonia oceanica made possible an attempt to set up and calibrate a Reliability Index (RI) for these ancient maps. Unfortunately, most of them appear to be totally unreliable. Some other maps are sufficient to provide a rough sketch of the location of the meadows, but not to assess possible changes with time. Finally, a very few recent maps are sufficiently accurate to allow cautious assumptions on meadow dynamics. It is worth noting that (i) whatever the cartographical method, no map of benthic communities is accurate everywhere and at all scales; (ii) the relevance of a map is dependent upon the purpose for which it was established or the utilization that is intended, e.g. short term monitoring of the meadow's state of health, long term dynamics, coastal development or management of a high value natural heritage community.

\section{Acknowledgements}

The authors acknowledge with thanks Stellio Casas and Gilles Hervé (IFREMER) and Vanina Pasqualini (University of Corsica) for stimulating discussions, Gilles Gascon, René Quinquis (IFREMER) and Philippe Clabaut for scan side sonar assistance, Gwenael Cadiou, Frédéric Bachet, Boris Daniel, Catherine Geoffrey and Loïc de Maisonneuve, for scuba diving assistance, the editor and two anonymous referees for their valuable comments. This work was performed as part of the Posicart programme, funded by the Conseil Régional Provence-Alpes Côte d'Azur, the Agence de l'Eau and the French Ministry of the Environment.

\section{References}

Alcoverro, T., Manzanera, M., Romero, J., 2001. Annual metabolic carbon balance of the seagrass Posidonia oceanica: the importance of carbohydrate reserves. Marine Ecology Progress Series 211, $105-116$.

Ardizzone, D., Pelusi, P., 1984. Yield and damage evaluation of bottom trawling on Posidonia meadows. In: Boudouresque, C.F., Jeudy de Grissac, A., Olivier, J. (Eds.), First International Workshop on Posidonia oceanica Beds. Gis Posidonie Publ., Marseille, pp. 63-72.

Augier, H., Boudouresque, C.F., 1970. Végétation marine de l'île de Port-Cros (Parc National). V. La Baie de Port Man et le problème de la régression de l'herbier à Posidonie. Bulletin du Muséum d'Histoire Naturelle de Marseille 30, 145-164.

Augier, H., Boudouresque, C.F., 1979. Premières observations sur l'herbier de posidonies et le Détritique côtier de l'île du Levant (Méditerranée, France) à l'aide du sous-marin Griffon de la Marine Nationale. Travaux scientifiques du Parc national de Port-Cros 5, 141-153. 
Belsher, T., Loubersac, L., Belbeoch, G., 1985. Remote sensing and mapping. In: Littler, M., Littler, D.S. (Eds.), Handbook of Phycological Methods. Ecological Field Methods: Macroalgae. University Press Publ., Cambridge, pp. 177-197.

Belsher, T., Meinesz, A., Lefèvre, J.R., Boudouresque, C.F., 1988. Simulation of SPOT satellite imagery for charting shallow-water benthic communities in the Mediterranean. P.S.Z.N. Marine Ecology 9, 157-165.

Ben Alaya, H., 1972. Répartition et conditions d'installation de Posidonia oceanica Delile et Cymodocea nodosa Ascherson dans le golfe de Tunis. Bulletin de l'Institut océanographique et des Pêches de Salammbô 2, 331-416.

Blanc, J.J., 1975. Recherches de sédimentologie appliquée au littoral rocheux de la Provence, aménagement et protection. Centre national pour l'exploitation des océans Publ., Paris. (163 pp.).

Boudouresque, C.F., Giraud, G., Thommeret, J., Thommeret, Y., 1980a. First attempt at dating by ${ }^{14} \mathrm{C}$ the undersea beds of dead Posidonia oceanica in the bay of Port-Man (Port-Cros, Var, France). Travaux scientifiques du Parc national de Port-Cros 6, 239-242.

Boudouresque, C.F., Thommeret, J., Thommeret, Y., 1980b. Sur la découverte d'un bioconcrétionnement fossile intercalé dans l'herbier à Posidonia oceanica de la baie de Calvi (Corse). In: Journées d'études des systèmes biogéographiques de Méditerranée, Cagliani. CIESM Publ., Monaco, pp. 139-142.

Boudouresque, C.F., Jeudy de Grissac, A., 1983. L'herbier à Posidonia oceanica en Méditerranée: les interactions entre la plante et le sédiment. Journal de Recherches océanographiques 8, 99-122.

Boudouresque, C.F., Bianconi, C.H., Meinesz, A., 1990. Live Posidonia oceanica in a coralligenous algal bank at Sulana bay, Corsica. Rapports et Procès-Verbaux des Réunions de la Commission internationale pour l'Exploration scientifique de la Méditerranée $32,11$.

Boudouresque, C.F., Gravez, V., Meinesz, A., Molenaar, H., Pergent, G., Vitiello, P., 1994. L'herbier à Posidonia oceanica en Méditerranée: protection légale et gestion. In: Pour qui la Méditerranée au $21^{\circ}$ siècle? Villes des rivages et environnement littoral en Méditerranée. Okéanos, Montpellier, pp. 209-220.

Boudouresque, C.F., Charbonnel, E., Meinesz, A., Pergent, G., Pergent-Martini, C., Cadiou, G., Bertrandy, M.C., Foret, P., Ragazzi, M., Rico-Raimondino, V., 2000. A monitoring network based on the seagrass Posidonia oceanica in the northwestern Mediterranean sea. Biologia marina mediterranea 7, 328-331.

Brown, C.J., Cooper, K.M., Meadows, W.J., Limpenny, D.S., Rees, H.L., 2002. Small-scale mapping of sea-bed assemblages in the eastern English Channel using sidescan sonar and remote sampling techniques. Estuarine, Coastal and Shelf Science 54, 263-278. (doi:10.1006/ecss.2001.0841).

Delgado, O., Ruiz, J., Perez, M., Romero, J., Ballesteros, E., 1999. Effects of fish farming on seagrass (Posidonia oceanica) in a Mediterranean bay: seagrass decline after organic loading cessation. Oceanologica Acta 32, 109-117.

Francour, P., 1997. Fish assemblages of Posidonia oceanica beds at Port-Cros (France, NW Mediterranean): assessment of composition and long-term fluctuations by visual census. P.S.Z.N. Marine Ecology 18, 157-173.

Francour, P., Ganteaume, A., Poulain, M., 1999. Effects of boat anchoring in Posidonia oceanica seagrass beds in the Port-Cros national Park (north-western Mediterranean Sea). Aquatic Conservation: Marine and Freshwater Ecosystems 9, 391-400.

Gambi, M.C., Buia, M.C., Casola, E., Scardi, M., 1989. Estimates of water movement in Posidonia oceanica beds: a first approach. In: Boudouresque, C.F., Meinesz, A., Fresi, E., Gravez, V. (Eds.), Second International Workshop on Posidonia Beds. GIS Posidonie Publ., Marseilles, pp. 101-112.

Iehlé, A., Wald, L., Boudouresque, C.F., 1995. Analyse et évaluation de la fiabilité de l'information dans le système d'information géographique des assemblages benthiques méditerranéens "MBA". Scientific Report of Port-Cros national Park 16, 93-113.

Lefèvre, J.R., Valério, C., Meinesz, A., 1984. Optimisation de la technique de photographie aérienne pour la cartographie des herbiers de Posidonies. In: Boudouresque, C.F., Meinesz, A., Fresi, E., Gravez, V. (Eds.), Second International Workshop on Posidonia Beds. GIS Posidonie Publ., Marseille, pp. 49-55.

Marion, A.F., 1883. Esquisse d'une topographie zoologique du Golfe de Marseille. Annales du Muséum d'Histoire Naturelle (Zoologie) de Marseille 1, 7-108.

Martín, M.A., Sánchez-Lizaso, J.L., Ramos-Esplá, A.A., 1997. Cuantificación del impacto de las artes de arrastre sobre la pradera de Posidonia oceanica (L.) Delile, 1813. Publicaciones especiales Instituto español de Oceanografía 23, 243-253.

Meinesz, A., Cuvelier, M., Laurent, R., 1981. Méthodes récentes de cartographie et de surveillance des herbiers de phanérogames marines. Leurs applications sur les côtes françaises de la Méditerranée. Vie et Milieu 31, 27-34.

Meinesz, A., Lefèvre, J.R., 1984. Régénération d'un herbier de Posidonia oceanica quarante années après sa destruction par une bombe dans la rade de Villefranche (Alpes-Maritimes, France). In: Boudouresque, C.F., Jeudy de Grissac, A., Olivier, J. (Eds.), First International Workshop on Posidonia oceanica Beds. GIS Posidonie Publ., Marseille, pp. 39-44.

Meinesz, A., Boudouresque, C.F., Lefevre, J.R., 1988. A map of the Posidonia oceanica beds of marina d'Elbu (Corsica, Mediterranean). P.S.Z.N. Marine Ecology 9, 243-252.

Meinesz, A., Belsher, T., Boudouresque, C.F., Lefèvre, J.R., 1991a. Première évaluation des potentialités du satellite SPOT pour la cartographie des peuplements benthiques superficiels de Méditerranée occidentale. Oceanologica Acta 14, 199-207.

Meinesz, A., Lefèvre, J.R., Astier, J.M., 1991b. Impact of coastal development on the infralittoral zone along the southern Mediterranean shore of continental France. Marine Pollution Bulletin 23, 343-347.

Meinesz, A., Boudouresque, C.F., de Vaugelas, J., Chiaverini, D., 1998. Carte des biocénoses sous-marines de la baie d'Elbo (reserve naturelle de Scandola). Travaux scientifiques du Parc naturel régional et des Réserves de Corse 57, 163-169.

Molinier, R., Picard, J., 1952. Recherches sur les herbiers de Phanérogames marines du littoral méditerranéen français. Annales de l'Institut océanographique 27, 157-234.

Mossé, R.A., 1984. Recherches lépidochronologiques sur Posidonia oceanica. Rhizomes plagiotropes et orthotropes des herbiers profonds de Port-Cros (Méditerranée, Fr.). Travaux Scientifiques du Parc national de Port-Cros 10, 87-107.

Ott, J.A., 1979. Persistence of a seasonal growth rhythm in Posidonia oceanica (L.) Delile under constant condition of temperature and illumination. Marine Biology Letters 1, 99-104.

Paillard, M., Gravez, V., Clabaut, P., Walker, P., Blanc, J.J., Boudouresque, C.F., Belsher, T., Urscheler, F., Poydenot, F., Sinnassamy, J.M., Augris, C., Peyronnet, J.P., Kessler, M., Augustin, J.M., Le Drezen, E., Prudhomme, C., Raillard, J.M., Pergent, G., Hoareau, A., Charbonnel, E., 1993. Cartographie de l'herbier de Posidonie et des fonds marins environnants de Toulon à Hyères (Var, France). Reconnaissance par sonar latéral et photographie aérienne. Notice de présentation. IFREMER \& GIS Posidonie Publ., Marseille. (36 pp.).

Pasqualini, V., Pergent-Martini, C., Clabaut, P., Pergent, G., 1998. Mapping of Posidonia oceanica using aerial photographs and side scan sonar: application off the Island of Corsica (France). Estuarine, Coastal and Shelf Science 47, 359-367/. (doi:10.1006/ecss.1998.0361).

Pasqualini, V., Pergent-Martini, C., Pergent, G., 1999. Environmental impact identification along the Corsican coast (Mediterranean sea) using image processing. Aquatic Botany 65, 311-320.

Pasqualini, V., Clabaut, P., Pergent, G., Benyousse, L., PergentMartini, C., 2000. Contribution of side scan sonar to the 
management of Mediterranean littoral ecosystems. International Journal of Remote Sensing 21, 367-378.

Pergent, G., Romero, J., Pergent-Martini, C., Mateo, M.A., Boudouresque, C.F., 1994. Primary production, stocks and fluxes in the Mediterranean seagrass Posidonia oceanica. Marine Ecology Progress Series 106, 139-146.

Pergent, G., Mendez, S., Pergent-Martini, C., Pasqualini, V., 1999. Preliminary data on the impact of fish farming facilities on Posidonia oceanica meadows in the Mediterranean. Oceanologica Acta 22, 95-107.

Porcher, M., 1984. Impact des mouillages forains sur les herbiers à Posidonia oceanica. In: Boudouresque, C.F., Meinesz, A., Fresi, E., Gravez, V. (Eds.), First International Workshop on Posidonia oceanica Beds. Gis Posidonie Publ., Marseille, pp. 145-148.

Pruvot, G., 1897. Essai sur les fonds et la faune de la Manche Occidentale (côtes de Bretagne) comparés à ceux du Golfe du Lion. Archives de Zoologie expérimentale et générale 3, 510-684.
Ramos-Esplá, A.A., Aranda, A., Gras, D., Guillen, J.E., 1994. Impactos sobre las praderas de Posidonia oceanica (L.) Delile en el SE español: necesidad de establecer herramientas de ordenamiento y gestión del litoral. In: Pour qui la Méditerranée au $21^{\circ}$ siècle? Villes des rivages et environnement littoral en Méditerranée. Okéanos, Montpellier, pp. 64-69.

Ruiz, J.M., Romero, O.J., 2001. Effects of in situ experimental shading on the Mediterranean seagrass Posidonia oceanica. Marine Ecology Progress Series 215, 107-120.

Sánchez-Lizaso, J.L., Guillen-Nieto, J.E., Ramos-Esplá, A.A., 1990. The regression of Posidonia oceanica meadows in El Campello (SE Spain). Rapports et Procès-Verbaux des Réunions de la Commission internationale pour l'Exploration scientifique de la Méditerranée $32,7$.

Sørensen, T., 1948. A method of establishing groups of equal amplitude in plant sociology based on similarity of species content. Det Konelig Danske Videnskabernes Selskab, Biologiske Skrifter 5, 1-34. 